4. Літературознавчий словник-довідник / за ред. Р. Т. Гром'яка, Ю. І. Коваліва, В. І. Теремка. Київ: ВЦ «Академія», 2007. 752 с. (Nota bene).

5. Kästner E. Es gibt nichts Gutes, außer: Man tut es: Kurz und bündig. Epigramme. Zürich: Atrium Verlag AG, 2015. $112 \mathrm{~S}$.

DOI https://doi.org/10.30525/978-9934-26-110-7-29

\title{
ФУНКЦІОНУВАННЯ СТИЛІСТИЧНИХ ЗАСОБІВ У ДИПЛОМАТИЧНІЙ КОМУНІКАЦІї
}

Гольцова М. Г.

кандидат філологічних наук,

доиент кафедри романо-германських мов і перекладу

Національний університет біоресурсів і природокористування Украӥни м. Київ, Украӥна

\section{Давидова Т. В.}

кандидат філологічних наук,

старший викладач кафедри практики англійської мови

Сумський державний педагогічний університет імені А. С. Макаренка м. Суми, Украӥна

Сучасний світ характеризується розширенням дипломатичних і політичних зв'язків, а отже, проблема відповідності дипломатичних документів стилістичним нормам $\epsilon$ актуальною.

Дипломатична комунікація - це стійка система статусно-рольових відносин, що склалися в комунікативному просторі соціального інституту дипломатії. Англомовний дипломатичний дискурс $\epsilon$ розумовокомунікативною взаємодією, що здійснюється в інституційних умовах мовцями - фаховими дипломатами різних країн та адресантами по всьому світу з метою досягнення мовленнєвого впливу на адресата.

Дипломатична мова $\epsilon$ фаховою мовою, що черпає свої мовні ресурси 3 природної мови, а також розвиває свої особливості в певній спільноті мовців, орієнтованих навколо професійного, функціонального, соціально-економічного чи ідеологічного поля. Підготовка дипломатичної документації вимагає особливої уваги, оскільки необхідно ретельно зважувати кожне слово та речення. 
Дослідженням міжнародно-правового дискурсу в когнітивнокомунікативному аспекті займалася Кравченко Н.К. [4]. Судус Ю.В. уперше здійснила спробу комплексного прагматичного аналізу та класифікації дискурсивних тактик, що реалізують стратегію дискредитації у мовленні дипломата [6]. Кащишин Н.Є. розкрила поняття дипломатичного дискурсу [2], проаналізувала експресивність термінів англомовного дипломатичного дискурсу [3]. Особливості дипломатичного листування на матеріалі французької мови розглянула Мартинюк О.М. [5]. Гольцова М.Г. та Ходарченко А.В. у стоїй статті висвітлили загальну характеристику та жанрову типологію документів дипломатичного дискурсу [1].

У нашій науковій розвідці ми розглянемо специфіку відтворення мовностилістичних засобів, а саме використання епітетів, метафор, метонімії в англомовних дипломатичних документах.

У дипломатичній комунікації стилістичні засоби посилюють емоційність висловлювання, надають експресивності діловому стилю дипломатичних документів, хоча відразу варто зазначити, що використання епітетів $є$ досить спорадичним явищем у дипломатичній комунікації, $\mathrm{i}$ вони зазвичай використовується для посилення ввічливості ділового листування, переважно в листах-співчуттях, вітальних листівках, особистих листах, тощо, наприклад:

- In these moments of deep sorrow, the people of Cambodia may count on all our support and affection (VN).

- While sharing Your Excellency's profound grief, on behalf of the Ukrainian Government and my own, I am conveying to you and to the people of Singapore my most sincere condolences.

- 'Your Excellency's visit to Cambodia will significantly strengthen the bonds of excellent friendship and cooperation between our two nations (VN).

В англомовних дипломатичних документах почасти спостерігаємо метонімію. Тоді назви країн, столиць, державних установ та міністерств використовують у значенні держави та ії уряду:

- Waging armed aggression against Ukraine for 7 years, $\underline{\text { Russia has been }}$ grossly violating the UN Charter, this resolution, and its other international legal obligations (FMS).

- The Cabinet of Ministers, in its current composition enjoys support of a clear parliamentary majority comprising 250 MPs under participation of three factions,

- The Ministry of Foreign Affairs of the Hellenic Republic presents its compliments to the Embassy of the United States of America (VN).

- Ukraine is grateful to its partners for their unwavering and consistent support for the territorial integrity of our state (FMS). 
- By its aggressive actions, the Russian Federation, despite its status as a permanent member of the UN Security Council, undermines fundamental principles of the international legal order, including respect for the territorial integrity of sovereign states and the inviolability of borders (FMS).

Приклади метафор $\epsilon$ досить поширеним явищем, що слугує увиразненням дипломатичного висловлення, надання йому експресивності й образності:

- The two sides noted with satisfaction the identity of proximity of views of the two states on a number of major international problems and the process started to move (AofA).

- We reaffirm that NATO remains the cornerstone of our security and collective defence (JC).

- Despite the efforts undertaken by the Philippines to curb corruption, CESCR noted with concern that the phenomenon continued to be widespread (LC).

- Although some efforts had been made to broaden the borders of understanding of the actions taken by the G-20, many delegations felt that consultations should be held before any final policy decisions (MofU).

На думку Н.С. Кащишин [5; с. 95], у дипломатичних текстах метафори передають та формують певну ідеологію, спонукають до дії, сприяють встановленню ближчих контактів. Завдяки образу, який створює метафора, дипломатичне послання дозволяє впливати i домінувати. Використання метафори з метою ухильності, інакомовності, або прямого обману нерідко простежується у дипломатичному дискурсі, адже двозначність та ухильність - непоодиноке явище у дипломатичній комунікації.

Головними функціями дипломатичного дискурсу $\epsilon$ передача необхідної інформації, формування ціннісних орієнтацій і установок, спонукання до необхідної дії, вплив для зміни мотивації, установок, поведінки, закріплення і підтримання конвенціональних взаємовідносин. Використання мовностилістичних засобів у дипломатичних документах сприяє реалізації всіх зазначених вище функцій.

Перспективами подальших досліджень $є$ вивчення специфіки відтворення комунікативно-прагматичних характеристик англомовних дипломатичних документів.

\section{Література:}

1. Гольцова М.Г., Ходарченко А.В. The genre differentiation and linguistic peculiarities of English diplomatic discourse. Міжнародний філологічний часопис. Том 12, № 2. 2021. С. 104-107. https://doi.org/10.31548/philolog2021.02.104 
2. Кащишин Н.С. Генеза та функціонування терміносистеми англомовного дипломатичного дискурсу : автореф. дис.. ... канд. філол. наук : 10.02.04. Львів, 2013. 20 с.

3. Кащишин Н.С. Експресивність термінів англомовного дипломатичного дискурсу. Філологічні науки. 2014. Книга 2. С. 93-98.

4. Кравченко Н.К. Міжнародно-правовий дискурс: когнітивнокомунікативний аспект: дис. ... док. філол. наук: 10. 02. 15. Київ. 2007. $568 \mathrm{c}$.

5. Мартинюк О.М. Особливості дипломатичного листування (на матеріалі французької мови). Науковий вісник Міжнародного гуманітарного університету. Серія: Філологія 2 (38). Одеса. 2019. С. 111-114.

6. Судус Ю.В. Мовленнєві тактики реалізації стратегії дискредитації в англомовному дипломатичному дискурсі: автореф. дис. ... канд. філол. наук: 10.02.04. Запоріжжя, 2018. 21 с.

\section{Список джерел ілюстративного матеріалу}

7. (MofU) - Memorandum of understanding between the European Parliament and the Verkhovna Rada of Ukraine on a joint framework for Parliamentary support and capacity building. URL: http://www.europarl.europa.eu/thepresident/resource/static/files/mou_ epvru_030715.pdf

8. (NV) - NOTE VERBALE. URL: http://archive.unu.edu/hq/li brary/resource/UN-correspondence-manual.pdf

9. (AofA) - Application of Agreement. URL: http://www.un.org/ en/documents/index.html

10. (LC) - Letter of Credence. URL: http://archive.unu.edu/hq/ library /resource/UN-correspondence-manual.pdf

11. (VN) - Verbal note. URL: https://www.state.gov/ documents/ organization/ 92637.pdf

12. (FMS) - Foreign Ministry Statement. URL: https://mfa.gov.ua/ en/news/foreign-ministry-statement-46th-anniversary-un-general-assemblyresolution-definition-aggression

13. (JC) - Joint Communique. URL: https://tajikistan.mfa.gov.ua/ news/9211-joint-communique-by-ukraine-latvia-lithuania-and-polandcommemorating-the-decade-since-the-russian-aggression-against-georgia 